\title{
Dietary B vitamin and methionine intake and MTHFR C677T genotype on risk of colorectal tumors in Lynch syndrome: the GEOLynch cohort study
}

\author{
Audrey Y. Jung • Fränzel J. B. van Duijnhoven • \\ Fokko M. Nagengast - Akke Botma • Renate C. Heine-Bröring • \\ Jan H. Kleibeuker • Hans F. A. Vasen · Jan L. Harryvan • \\ Renate M. Winkels • Ellen Kampman
}

Received: 3 December 2013/ Accepted: 2 June 2014/Published online: 12 June 2014

(C) Springer International Publishing Switzerland 2014

\begin{abstract}
Purpose Dietary intake of B vitamins and methionine, essential components of DNA synthesis and methylation pathways, may influence colorectal tumor (CRT) development. The impact of B vitamins on colorectal carcinogenesis in individuals with Lynch syndrome (LS) is unknown but is important given their high lifetime risk of developing neoplasms. The role of MTHFR C677T genotype in modifying these relationships in LS individuals is also unclear. We investigated associations between dietary intakes of folate, vitamins B2, B6, B12, and methionine and CRT development in a prospective cohort study of 470 mismatch repair gene mutation carriers.

Methods Dietary intakes were assessed by food frequency questionnaire. Cox regression models with robust sandwich covariance estimation, adjusted for age, sex, physical activity, number of colonoscopies during persontime, NSAID use, and mutual vitamins were used to calculate hazard ratios (HRs) and $95 \%$ confidence intervals
\end{abstract}

A. Y. Jung · E. Kampman

Department for Health Evidence, Radboud University Medical Center, Nijmegen, Netherlands

F. J. B. van Duijnhoven - A. Botma · R. C. Heine-Bröring ·

J. L. Harryvan - R. M. Winkels · E. Kampman ( $\)$

Division of Human Nutrition, Wageningen University,

Wageningen, Netherlands

e-mail: Ellen.Kampman@wur.nl

F. J. B. van Duijnhoven

National Institute for Public Health and the Environment

(RIVM), Bilthoven, Netherlands

F. M. Nagengast

Department of Gastroenterology, Radboud University Medical

Center, Nijmegen, Netherlands
(95\% CIs). Analyses were also stratified by MTHFR C677T genotype.

Results During a median person-time of 28.0 months, 131 persons developed a CRT. Fifty-one of these persons developed an incident colorectal adenoma, while there were four persons who developed an incident colorectal carcinoma. Compared to the lowest tertile of intake, adjusted HRs (95\% CIs) for CRT development in the highest tertile were $1.06(0.59-1.91)$ for folate, 0.77 (0.39-1.51) for vitamin B2, $0.98(0.59-1.62)$ for vitamin B6, $1.24(0.77-2.00)$ for vitamin B12, and $1.36(0.83-2.20)$ for methionine. Low vitamin B2 and low methionine intake were statistically significantly associated with an increased risk of CRT in MTHFR 677TT individuals compared to a combined reference of persons with low intake and CC genotype.

Conclusions There was no suggestion that intake of any dietary B vitamin or methionine was associated with CRT development among those with LS.

\footnotetext{
J. H. Kleibeuker

Department of Gastroenterology and Hepatology, University Medical Center Groningen, Groningen, Netherlands

H. F. A. Vasen

Netherlands Foundation for the Detection of Hereditary Tumors, Leiden, Netherlands

E. Kampman

Department for Health Sciences, VU University Medical Center, Amsterdam, Netherlands
} 
Keywords B vitamins - Colorectal cancer - Colorectal adenoma $\cdot$ Lynch syndrome $\cdot$ Folate $\cdot$ Diet

\section{Introduction}

Lynch syndrome (LS), the most common form of hereditary colorectal cancer (CRC), is an autosomal dominant disorder. Individuals with LS carry inactivating germline mutations in one of the DNA mismatch repair (MMR) genes $M L H 1, M S H 2, M S H 6$, and PMS2 [1-4]. An additional cause of LS occurs when deletions affect the polyadenylation site of the epithelial cell adhesion molecule $(E P C A M)$ gene located upstream of $M S H 2$, leading to transcriptional readthrough, which silences $\mathrm{MSH} 2$ [5]. Compared to the general population, LS individuals are at considerably higher risk for developing CRC (penetrance to age 70 of 30-85 \% [612]), develop colorectal adenomas (CRAs) at a younger age, and have a higher lifetime risk for other types of cancers such as, but not exclusive to, those in the endometrium, ovary, and stomach [7, 13, 14]. CRAs, precursors of CRC $[15,16]$, progress through the adenoma-carcinoma sequence, which seems to be accelerated in LS [17-19].

Overweight [20, 21], smoking [22-24], and a dietary pattern containing high amounts of fried and fast food snacks [25] have previously been reported to increase the risk of CRA in LS, whereas fruit consumption [23] and daily aspirin use [26] decreased CRC risk. This indicates that modifiable lifestyle factors in addition to genetic factors are important among this high-risk population.

$B$ vitamins and methionine are essential for nucleotide synthesis, and DNA methylation and repair reactions. Folate plays a central role in mediating one-carbon units for both DNA synthesis and DNA methylation, the two main pathways in folate-mediated one-carbon metabolism. The other B vitamins act as cofactors in folate metabolism reactions, and methionine is converted to $S$-adenosylmethionine (SAM), the universal methyl donor for cellular methylation reactions. Decades of research into the role of $B$ vitamins and methionine in colorectal tumor (CRT) development in the general population have resulted in the majority of studies pointing toward an inverse association between folate intake and risk of sporadic CRA [27-29], but inconsistencies [30-33] have prompted hesitation by the World Cancer Research Fund Continuous Update Project in drawing firm conclusions [34]. Similarly, the relationships between other B vitamins and methionine and CRT development remain unresolved.

The common $677 \mathrm{C} \rightarrow \mathrm{T}$ single nucleotide polymorphism (SNP) in the methylenetetrahydrofolate reductase $(M T H F R)$ gene, vital for folate-mediated one-carbon metabolism, by itself has been shown to be inversely related to CRC risk [35, 36], but likely depends on folate status. While extensive strides in research have been made to elucidate the associations between $\mathrm{B}$ vitamin and methionine intake and risk of sporadic CRT, there still remains a paucity of data describing these relationships in a LS population, where given their high lifetime risk of developing neoplasms and the current contentious nature of $\mathrm{B}$ vitamins in CRT development, uncovering whether B vitamin and methionine intake can modify this risk would be certainly pertinent.

To the best of our knowledge, no studies have previously examined dietary B vitamin intake in relation to colorectal adenomas or carcinomas in a LS population. We, therefore, conducted a prospective cohort study to evaluate the associations between dietary folate, vitamin B2, vitamin B6, vitamin B12, and methionine intake and CRT (colorectal adenoma or carcinoma) development in individuals with LS. We also assessed whether MTHFR C677T genotype modified these relationships.

\section{Materials and methods}

Study subjects

The GEOLynch prospective cohort study has been previously described [20]. Briefly, all eligible MMR gene mutation carriers were identified at the Netherlands Foundation for the Detection of Hereditary Tumors (NFDHT) in Leiden, the Radboud University Medical Center (RUMC) in Nijmegen, and the University Medical Center Groningen (UMCG) in Groningen (all in the Netherlands). Information about MMR gene mutation carrier status was collected at the NFDHT. Eligible patients were Dutch-speaking, Caucasian, mentally competent to participate men and women between 18 and 80 years of age who were screened regularly by colonoscopy. Terminally ill patients and those with familial adenomatous polyposis (FAP), inflammatory bowel diseases, and a history of a complete proctocolectomy or colostomy were excluded.

Between July 2006 and July 2008, a total of 713 MMR gene mutation carriers appeared to be eligible to participate in the study after approval by their medical specialist. Nine participants were ineligible. A total of 499 individuals (71\% of 704) were willing to participate in the study. We were unable to retrieve medical and personal information from 29 participants. In total, 470 persons from at least 161 families were included in this study. Approval for this study was given by the RUMC medical ethical committee. All participants provided written informed consent.

\section{Exposure assessment}

Usual dietary intake was assessed by a validated 183 -item semiquantitative self-administered food frequency questionnaire 
(FFQ) [37, 38]. Using this FFQ, subjects reported types and portions of food they consumed within the last month. Response choices for frequency were never, 1, 2-3 days/month, 1, 2-3, 4-5, 6-7 days/week. Response choices for portion size relative to a standard portion were half portion, 1 portion, 1.5 portions, 2 or more portions. Dietary intake of folate ( $\mu \mathrm{g}$ dietary folate equivalents/day), vitamin B2 (mg/day), vitamin B6 (mg/day), vitamin B12 ( $\mu \mathrm{g} /$ day), methionine (mg/day), alcohol (g/day), and total energy (kJ/day) were calculated using the Dutch food composition table from 2006 [39]. Information about age, sex, medical history, and lifestyle factors, such as smoking status, physical activity [40], BMI, NSAID use, and education level were obtained from a standardized self-administered questionnaire.

The FFQ used in this study has been validated in estimating dietary intake of folate and vitamin B12 using the method of triads (FFQ, $24 \mathrm{~h}$ questionnaire, and corresponding biomarkers) [38], but not for this cohort specifically. The wide geographical distribution of all the participants in our cohort made it particularly challenging to collect additional information from participants, but we have managed to obtain blood from 81 persons with LS in this cohort. Plasma concentrations of folate and other B vitamins were measured, and Spearman's correlation coefficients between $\mathrm{B}$ vitamin intake and related biomarkers were 0.11 for folate, 0.13 for vitamin B2, 0.13 for vitamin B6, -0.05 for vitamin B12, and 0.24 for methionine, demonstrating poor correlation between dietary intake and plasma vitamers. This is not surprising, as dietary folate intake and plasma folate are usually poorly correlated [41-43].

More specifically, for the population in which our FFQ was validated, the correlation coefficient between serum folate and the FFQ was 0.20 , similar to blood folate-FFQ folate correlations from other studies [41-43]. The minor differences between this correlation coefficient and the one from our Lynch population could be due to, for example, differences in blood collection protocols, methods to measure plasma/serum folate, time between blood collection and analysis, seasonal variation, and sample size.

\section{MTHFR genotyping}

Participants were provided an Oragene DNA self-collection kit for saliva collection. Genotyping of the MTHFR C677T polymorphism was determined using TaqMan $^{\circledR}$ in accordance with the information provided from the Applied Biosystems website (http://www.appliedbiosys tems.com) in DNA extracted from saliva (DNA Genoteck Inc). Laboratory staff was blinded to the clinical outcome status of the patients donating a saliva sample. To assess reproducibility, genotyping was repeated for $10 \%$ of the samples, and complete concordance was found between the two sets of results. Genotype frequencies were in HardyWeinberg equilibrium as tested by a $\chi^{2}$ test $(p>0.05)$.

\section{Outcome data}

Information about CRTs from colonoscopies was determined at the NFDHT [44] and from medical records at RUMC and UMCG. Information about colonic surgeries, CRCs, and CRAs from prior colonoscopies was also collected before recruitment and during follow-up until December 2010. Location, size, and histology for all documented tumors were obtained from pathology reports.

\section{Statistical analyses}

Total energy-adjusted nutrient intake was computed using the linear residuals method [45]. Descriptive statistics were used to describe the baseline characteristics for the total population of MMR carriers $(n=470)$ stratified by tertiles of folate intake.

Cox proportional hazards regression was used to calculate hazard ratios (HRs) and $95 \%$ confidence intervals (CIs) to estimate risk of developing CRTs from dietary B vitamin and methionine intake. Robust sandwich covariance estimation was used to account for dependency of observations within families. The lowest tertile of B vitamin and methionine intake was set as the reference category. The crude model included age and sex as covariates. The following were evaluated as possible confounders: age (continuous), sex, BMI (continuous), history of CRTs (yes/ no), number of colonoscopies during person-time (continuous), NSAID use ( $<1 / \geq 1$ per week), education (high vs. lower educated), physical activity (high vs. lower physical activity), smoking (current/former/never), alcohol (continuous), energy intake (continuous), dietary fiber (continuous), supplement use (yes/no). A covariate was considered to be a confounder if it was associated with vitamin intake and was also a risk factor for CRT; additionally, the covariate must have changed one of the HRs by at least $10 \%$ using manual backward selection. For all vitamins, the fully adjusted model included age, sex, physical activity (high vs. lower), number of colonoscopies during persontime (continuous), and NSAID use ( $<1 / \geq 1$ per week). A fully adjusted model including mutual B vitamins (continuous) and methionine (continuous) was also constructed.

Person-time started at the time of questionnaire completion and ended at the date of colonoscopy at which the first colorectal adenoma was diagnosed during follow-up. For colorectal carcinomas during follow-up, the end date was the date of carcinoma diagnosis. For those without a detectable CRT during follow-up, censoring was at the date of their last known colonoscopy. 
Table 1 Baseline characteristics of the population by total energy-adjusted folate intake

\begin{tabular}{|c|c|c|c|}
\hline & $\begin{array}{l}\text { Low folate intake } \leq 183.71 \\
\mu \mathrm{g} / \text { day }(n=155)\end{array}$ & $\begin{array}{l}\text { Medium folate intake } \\
183.72-224.29 \mu \mathrm{g} / \text { day }(n=156)\end{array}$ & $\begin{array}{l}\text { High folate intake }>224.29 \\
\mu \mathrm{g} / \text { day }(n=155)\end{array}$ \\
\hline Person-months, median (IQR) & $27.2(17.3-38.9)$ & $28.9(17.3-39.0)$ & $29.7(16.5-40.0)$ \\
\hline \multicolumn{4}{|l|}{ Patient characteristics } \\
\hline Age (years), median (IQR) & $46.8(39.1-56.7)$ & $48.3(39.4-57.7)$ & $53.1(45.1-60.7)$ \\
\hline Sex (female), $n(\%)$ & $91(58.7)$ & $96(61.5)$ & $92(59.4)$ \\
\hline BMI $\left(\mathrm{kg} / \mathrm{m}^{2}\right)$, median (IQR) & $24.4(21.8-27.4)$ & $24.8(22.8-26.9)$ & $24.2(22.7-26.3)$ \\
\hline Higher education, $n(\%)^{\mathrm{a}}$ & $41(26.6)$ & $56(36.1)$ & $61(40.1)$ \\
\hline \multicolumn{4}{|l|}{ Dietary vitamin intakes, median $(I Q R)$} \\
\hline Vitamin B2 (mg/day) & $1.5(1.2-1.7)$ & $1.6(1.4-1.9)$ & $1.9(1.7-2.2)$ \\
\hline Vitamin B6 (mg/day) & $1.7(1.5-1.9)$ & $1.9(1.7-2.1)$ & $2.0(1.8-2.2)$ \\
\hline Vitamin B12 ( $\mu \mathrm{g} /$ day $)$ & $3.4(2.6-4.3)$ & $3.8(3.1-4.7)$ & $4.2(3.4-5.8)$ \\
\hline Methionine (mg/day) & $1,233.9(1,106.1-1,413.9)$ & $1,359.9(1,175.1-1,503.3)$ & $1,388.7(1,269.0-1,569.2)$ \\
\hline \multicolumn{4}{|l|}{ Other dietary and lifestyle factors } \\
\hline Energy (kJ/day), median (IQR) & $8,750.3(7,095.4-10,735.9)$ & $8,181.1(6,800.8-10,269.4)$ & $8,876.9(7,337.2-10,969.7)$ \\
\hline Vegetable (g/day), median (IQR) & $72.8(50.5-110.8)$ & $125.2(88.3-161.9)$ & $177.2(136.0-224.3)$ \\
\hline Fruit (g/day), median (IQR) & $80.8(42.4-166.2)$ & $154.9(79.8-232.2)$ & $226.6(149.6-333.6)$ \\
\hline Dietary fiber (g/day), median (IQR) & $20.2(15.7-25.2)$ & $24.0(19.7-29.3)$ & $28.8(24.3-34.1)$ \\
\hline Red meat intake (g/day), median (IQR) & $48.7(40.5-72.0)$ & $47.3(30.7-63.8)$ & $42.7(24.4-54.1)$ \\
\hline Supplement use $^{\mathrm{b}}, n(\%)$ & $39(25.2)$ & $43(27.6)$ & $46(29.7)$ \\
\hline Alcohol (g/day), median (IQR) & $7.2(1.6-17.3)$ & $7.3(0.9-16.0)$ & $6.8(1.8-16.5)$ \\
\hline \multicolumn{4}{|l|}{ Smoking status, $n(\%)$} \\
\hline Current & $38(24.5)$ & $30(19.2)$ & $16(10.3)$ \\
\hline Former & $61(39.4)$ & $61(39.1)$ & $80(51.6)$ \\
\hline Never & $56(36.1)$ & $65(41.7)$ & $58(37.4)$ \\
\hline NSAID use (<1/week), $n(\%)$ & $134(86.5)$ & $140(89.7)$ & $140(90.3)$ \\
\hline High physical activity, $n(\%)^{\mathrm{c}}$ & $46(30.1)$ & $43(28.1)$ & $62(41.1)$ \\
\hline \multicolumn{4}{|l|}{ Clinical characteristics, $n(\%)$} \\
\hline History of colorectal tumors & $79(51.0)$ & $76(48.7)$ & $76(49.0)$ \\
\hline History of other cancers & 18 (11.6) & $25(16.0)$ & $39(25.2)$ \\
\hline \multicolumn{4}{|l|}{ Colonoscopies during person-time } \\
\hline 1 & $64(41.3)$ & $49(31.4)$ & $61(39.4)$ \\
\hline 2 & $65(41.9)$ & $71(45.5)$ & $59(38.1)$ \\
\hline$\geq 3$ & $26(16.8)$ & $35(22.4)$ & $34(21.9)$ \\
\hline \multicolumn{4}{|l|}{ MMR gene mutation } \\
\hline MLH1 & $59(38.1)$ & $66(42.3)$ & $52(33.6)$ \\
\hline MSH2 & $65(41.9)$ & $64(41.0)$ & $62(40.0)$ \\
\hline MSH6 & $30(19.4)$ & $23(14.7)$ & $40(25.8)$ \\
\hline PMS2 & $0(0.0)$ & $2(1.3)$ & $1(0.7)$ \\
\hline \multicolumn{4}{|l|}{ MTHFR C677T genotype, $n(\%)$} \\
\hline $\mathrm{CC}$ & $60(42.0)$ & $60(40.5)$ & $62(41.6)$ \\
\hline $\mathrm{CT}$ & $64(44.8)$ & $73(49.3)$ & $78(52.4)$ \\
\hline TT & $19(13.3)$ & $15(10.1)$ & $9(6.0)$ \\
\hline
\end{tabular}

a College or university degree

b Regular use of any folic acid- or B vitamin-containing supplement in the last month

${ }^{c}$ Highest tertile of physical activity score

Effect measure modification by MTHFR C677T genotype was investigated by stratification. We performed a median split for each vitamin intake and we chose low folate, low vitamin B2, low vitamin B6, low vitamin B12, and low methionine intakes in those with the $\mathrm{CC}$ genotype as the reference category. To test for multiplicative 
nutrient-gene interaction, we created a product term between B vitamin intake (low/high) and MTHFR C677T genotype and included this term into our final model. We also examined possible interactions between dietary intakes of folate, vitamin B2, vitamin B6, vitamin B12, methionine, alcohol (low/high) and smoking status (never, former, current), where a combination of low intakes with either low alcohol intake or never smokers was chosen as the reference category. For stratification by MMR gene mutation, we set low intake as the reference for each of the genes $M L H 1, M S H 2$, and MSH6. There was not enough statistical power to stratify by $P M S 2$.

The lifetest procedure was used to evaluate whether the proportional hazards models met the assumption of proportionality; no violation of the proportional hazards assumption was observed by visual inspection. Sensitivity analyses were performed by (1) excluding those with a history of CRTs before the start of the study period $(n=232)$ and (2) excluding those who developed CRCs during follow-up $(n=7)$. All analyses were performed using SAS version 9.2 (SAS Institute, Cary, NC, USA).

\section{Results}

In this prospective cohort study of MMR gene mutation carriers, 131 of 470 persons developed a CRT during a median person-time of 28.0 months. Table 1 shows the baseline characteristics of the total cohort stratified by tertiles of folate intake. There was a greater proportion of females in the medium folate intake group compared to the low- and high-intake groups. Compared to individuals in the lowest tertile of folate, persons in the highest tertile of folate, were older, had a higher education, reported higher intakes of vitamin B2, B6, B12, methionine, and had a higher consumption of vegetables, fruit, and dietary fiber. In addition, those in the highest tertile of folate were less likely to be current smokers and more likely to be highly physically active compared with the lowest folate tertile. While those in the highest tertile of folate intake were less likely to have a history of CRTs, they were more likely to have a history of other cancers, compared to those in the lowest tertile.

As can be seen in Table 2, there was no evidence of a clear association between dietary intake of any B vitamin or methionine and CRT risk after adjusting for age, sex, physical activity, number of colonoscopies during persontime, and NSAID use, nor when mutual vitamins and methionine were included as covariates. Compared to the lowest tertile of intake, adjusted HRs (including mutual B vitamins and methionine) for CRT risk and corresponding $95 \%$ CIs for the highest tertile were $1.06(0.59-1.91)$ for folate, $0.77(0.39-1.51)$ for vitamin B2, $0.98(0.59-1.62)$ for vitamin B6, $1.24(0.77-2.00)$ for vitamin $\mathrm{B} 12$, and 1.36 (0.83-2.20) for methionine.

We did not observe an association between MTHFR C677T genotype and risk of CRT (data not shown). Table 3 shows that there was no evidence of effect measure modification by MTHFR C677T genotype in the associations between dietary vitamin $\mathrm{B}$ and methionine intake and CRT risk ( $p$ for interaction $>0.05$ for all). However, it is worthy to note that there was a significant increased risk for developing CRT in LS patients homozygous for the variant MTHFR C677T allele who consumed low amounts of vitamin B2 compared to those in the reference category (HR 2.44, $95 \%$ CI 1.20-4.93), while a non-significant reduction in CRT risk was seen for high vitamin B2 intake in combination with the MTHFR 677TT genotype. We observed a similar relationship between methionine intake and CRT risk-a significant increased risk for individuals with the MTHFR 677TT genotype in combination with low methionine intake compared to low methionine intake in MTHFR 677CC individuals (HR 2.64, 95 \% CI 1.06-6.58), whereas no evidence of an association with CRT risk was seen for high methionine intake in combination with the TT genotype.

Investigations for possible interactions between dietary vitamins and smoking and alcohol in the development of CRT showed a significant interaction between dietary folate and alcohol intake ( $p$ for interaction $=0.02$ ). Compared to low folate/low alcohol, adjusted HRs and corresponding $95 \%$ CIs were $0.56(0.29-1.09)$ for high folate/ low alcohol, 0.84 (0.46-1.54) for low folate/high alcohol, $1.23(0.66-2.32)$ for high folate/high alcohol. There was no evidence of an interaction between any vitamin and smoking, nor were there any suggestions for interactions between the other vitamins (all $p$ interaction $>0.05$ ). Stratification by MMR gene mutation showed no striking differences for the different mutations. Compared to low folate intake, adjusted HRs and $95 \%$ CIs for high folate intake were $1.11(0.49-2.51)$ for $M S H 1$ mutation carriers, $1.64(0.82-3.29)$ for $M S H 2$ mutation carriers, and 0.42 (0.12-1.48) for MSH6 mutation carriers.

In sensitivity analyses, B vitamin and methionine intake did not appear to be associated with CRT risk when those with prevalent tumors during person-time were excluded. Compared to the lowest tertile of intake, adjusted HRs including mutual vitamins and corresponding $95 \%$ CIs for the highest tertile of intake was $0.59(0.19-1.85)$ for folate, $0.82(0.25-2.69)$ for vitamin B2, $1.98(0.77-5.06)$ for vitamin B6, $1.56(0.69-3.51)$ for vitamin $\mathrm{B} 12$, and 1.65 (0.74-3.68) for methionine. Restricting analyses to those who developed a CRA during person-time, adjusted HRs including mutual vitamins for developing CRA and corresponding $95 \%$ CIs for the highest tertile was 1.02 (0.56-1.86) for folate, $0.82(0.42-1.60)$ for vitamin B2, 
Table 2 Hazard ratios for B vitamin and methionine intake and colorectal tumor risk in MMR mutation carriers

\begin{tabular}{|c|c|c|c|c|c|}
\hline & $\begin{array}{l}\text { Cases/cohort, } \\
n(122 / 448)\end{array}$ & $\begin{array}{l}\text { Person-time (months), } \\
\text { median (IQR) }\end{array}$ & $\begin{array}{l}\text { Age and sex } \\
\text { adjusted }(95 \% \mathrm{CI})\end{array}$ & $\begin{array}{l}\text { Fully adjusted } \\
\text { HR }(95 \% \mathrm{CI})^{\mathrm{a}}\end{array}$ & $\begin{array}{l}\text { Fully adjusted } \\
\mathrm{HR}+\text { mutual vitamins } \\
(95 \% \mathrm{CI})^{\mathrm{a}}\end{array}$ \\
\hline \multicolumn{6}{|l|}{ Dietary factor } \\
\hline \multicolumn{6}{|l|}{ Folate $(\mu \mathrm{g} /$ day $)$} \\
\hline$\leq 183.71$ & $38 / 150$ & $27.2(17.3-38.9)$ & 1.00 (Ref.) & 1.00 (Ref.) & 1.00 (Ref.) \\
\hline $183.72-224.29$ & $42 / 149$ & $28.9(17.3-39.0)$ & $1.01(0.65-1.56)$ & $1.19(0.75-1.90)$ & $1.27(0.77-2.08)$ \\
\hline \multirow[t]{2}{*}{$>224.29$} & $42 / 149$ & $29.7(16.5-40.0)$ & $1.02(0.64-1.62)$ & $0.91(0.56-1.48)$ & $1.06(0.59-1.91)$ \\
\hline & & & $p$ trend & 0.52 & 0.91 \\
\hline \multicolumn{6}{|l|}{ Vitamin B2 (mg/day) } \\
\hline$\leq 1.49$ & $41 / 149$ & $27.2(18.5-38.9)$ & 1.00 (Ref.) & 1.00 (Ref.) & 1.00 (Ref.) \\
\hline $1.50-1.83$ & $43 / 149$ & $27.9(15.5-38.4)$ & $1.04(0.68-1.58)$ & $0.98(0.62-1.55)$ & $1.01(0.59-1.70)$ \\
\hline \multirow[t]{2}{*}{$>1.83$} & $38 / 150$ & $33.1(18.3-40.8)$ & $0.82(0.55-1.22)$ & $0.73(0.46-1.15)$ & $0.77(0.39-1.51)$ \\
\hline & & & $p$ trend & 0.10 & 0.35 \\
\hline \multicolumn{6}{|l|}{ Vitamin B6 (mg/day) } \\
\hline$\leq 1.75$ & $44 / 148$ & $25.5(15.6-38.1)$ & 1.00 (Ref.) & 1.00 (Ref.) & 1.00 (Ref.) \\
\hline $1.76-2.00$ & $36 / 149$ & $30.2(18.5-40.6)$ & $0.69(0.47-1.03)$ & $0.76(0.51-1.13)$ & $0.81(0.52-1.28)$ \\
\hline \multirow[t]{2}{*}{$>2.00$} & $42 / 151$ & $29.9(16.4-40.0)$ & $0.83(0.53-1.29)$ & $0.83(0.55-1.26)$ & $0.98(0.59-1.62)$ \\
\hline & & & $p$ trend & 0.32 & 0.98 \\
\hline \multicolumn{6}{|l|}{ Vitamin B12 ( $\mu \mathrm{g} /$ day) } \\
\hline$\leq 3.33$ & $37 / 149$ & $28.8(16.5-39.7)$ & 1.00 (Ref.) & 1.00 (Ref.) & 1.00 (Ref.) \\
\hline $3.34-4.46$ & $41 / 147$ & $29.3(19.2-39.5)$ & $1.11(0.73-1.67)$ & $1.00(0.64-1.59)$ & $1.14(0.71-1.85)$ \\
\hline \multirow[t]{2}{*}{$>4.46$} & $44 / 152$ & $27.7(16.2-39.3)$ & $1.13(0.76-1.68)$ & $1.00(0.66-1.52)$ & $1.24(0.77-2.00)$ \\
\hline & & & $p$ trend & 0.83 & 0.45 \\
\hline \multicolumn{6}{|l|}{ Methionine (mg/day) } \\
\hline$\leq 1,226.33$ & $42 / 153$ & $27.9(18.1-38.5)$ & 1.00 (Ref.) & 1.00 (Ref.) & 1.00 (Ref.) \\
\hline $1,226.34-1,450.02$ & $35 / 152$ & $28.0(18.0-39.8)$ & $0.75(0.46-1.22)$ & $0.88(0.52-1.50)$ & $1.00(0.57-1.74)$ \\
\hline \multirow[t]{2}{*}{$>1,450.02$} & $45 / 143$ & $28.3(15.4-39.4)$ & $1.08(0.73-1.59)$ & $1.08(0.71-1.66)$ & $1.36(0.83-2.20)$ \\
\hline & & & $p$ trend & 0.82 & 0.22 \\
\hline
\end{tabular}

${ }^{a}$ Fully adjusted for age, sex, number of colonoscopies during person-time, NSAID use, and physical activity

$0.95(0.57-1.58)$ for vitamin B6, $1.18(0.73-1.93)$ for vitamin B12, and 1.60 (0.97-2.60) for methionine compared to the lowest tertile of intake.

\section{Discussion}

In this prospective cohort study of MMR gene mutation carriers, our results do not suggest an association between dietary folate, vitamin B2, vitamin B6, vitamin B12, and methionine intake and risk of CRT development. There was also no evidence of effect measure modification by MTHFR C677T genotype in the relationship between any $\mathrm{B}$ vitamin or methionine and CRT risk. There was, however, suggestion that low vitamin B2 intake in MTHFR 677TT individuals was related to increased risk of CRT compared to low intake in 677CC. Likewise, the same pattern was observed for methionine intake; low intake of methionine in MTHFR 677TT was associated with an increased risk of CRT compared to low intake in MTHFR 677CC persons.

The role of $\mathrm{B}$ vitamin and methionine intake in the development of CRT is an area of considerable and ongoing interest; although the evidence is not entirely consistent, there is general consensus that dietary intake of folate is inversely associated with risk of sporadic CRT in the general population. Indeed, for dietary folate intake, inverse [27, 28, 46], null [30, 33, 47, 48], and direct [32] associations with risk of CRT have been reported in both cohort [28, 33, 46, 47] and case-control studies [27, 30, 32, 48] investigating these relationships. Most recently, a meta-analysis of cohort studies investigating dietary folate intake and CRC risk performed by the World Cancer Research Fund/American Institute for Cancer Research as part of their Continuous Update Project did not reveal significant evidence that dietary folate is associated with CRC, nor did plasma/serum folate seem to be associated with CRC in similar meta-analyses [49]. On the other hand, 


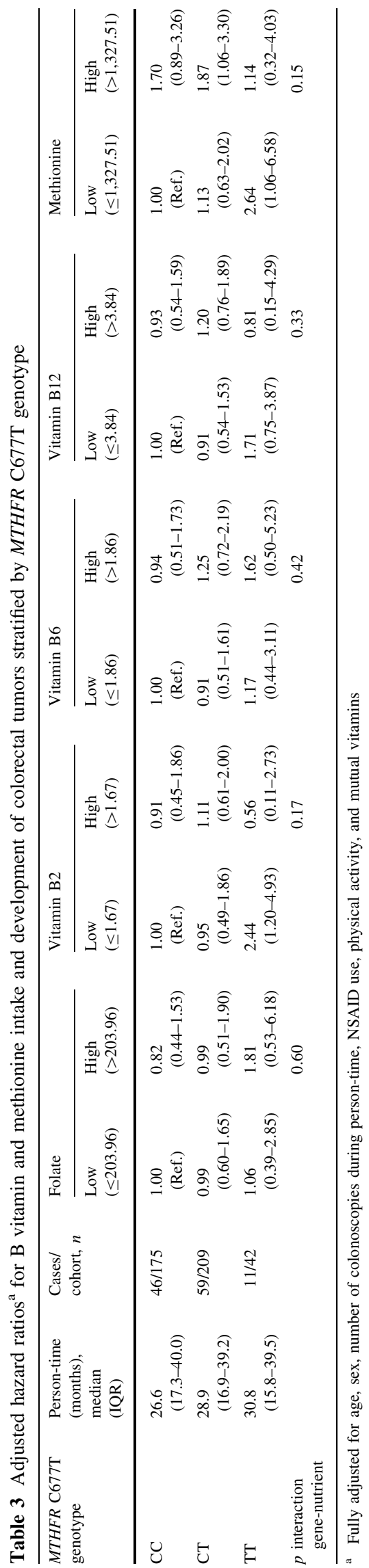

results of a pooled analysis of 13 cohort studies indicated a lower risk of CRC in persons with high folate intake compared to persons with low folate intake [50].

Vitamin B2 intake has been directly associated with CRA risk in a Dutch case-control study [32], but unassociated with CRT in other studies [30, 31, 33, 47]. A meta-analysis of prospective studies revealed an inverse association between vitamin B6 intake and CRC risk [51], while other studies did not $[30,31,33,52]$. There are also accounts of no association between vitamin B12 and CRT risk [30, 31]. Likewise, methionine intake has been both unassociated with CRT risk [31, 47], and inversely associated [33]. Given these inconsistencies, the relationship between folate [53], other B vitamins and methionine and sporadic CRT development remains unresolved.

A dual role of folic acid in CRC development has been proposed, where folic acid supplementation can either prevent or promote CRC development and progression depending on the stage of cell transformation at the time of intervention [54]. In normal tissues, folic acid supplementation has been shown to prevent the development of CRC but promotes the progression of established preneoplastic or neoplastic lesions. This concept has been validated in animal models $[55,56]$. Perhaps of particular pertinence is the study of folic acid supplementation in $\mathrm{APC}+/-\mathrm{MSH} 2-/-$ mice, which are more phenotypically and genotypically similar to human CRC compared with other mouse models and resemble FAP and LS, respectively, in humans [56]. The concept of a dual role of folic acid in CRC is still controversial in humans given inconsistent results between studies [57-60]. MMR gene mutation carriers are at high risk for developing CRC and provide a good human model in which to explore the concept of a dual role. We have investigated dietary folate, other B vitamins, and methionine intake rather than folic acid supplementation, as less than one-third of our population has used B vitamin-containing supplements.

Our results are in agreement with previous reports of null associations between dietary folate intake in sporadic CRT [30, 31, 33], as well as with those from meta-analyses of randomized controlled trials of folic acid [57, 61, 62] and combined folic acid, vitamin B6, and vitamin B12 supplementation and sporadic CRA development [59]. Various explanations could possibly account for the mixed findings between observational studies. We considered that range of dietary folate intake could influence the direction of the associations, but examination of the data does not appear to show this to be a factor, as narrow ranges of dietary folate intake have been reported to be inversely associated [63], directly associated [32], and unassociated [33] with risk of CRT ( $<150$ vs. $>212,<191$ vs. $>220$, $<168$ vs. $>297 \mu \mathrm{g} /$ day, respectively). Additionally, dietary folate intake could be higher in the USA and Canada 
compared to countries in Europe such as the Netherlands, where mandatory food fortification does not exist, and this could also alter development of CRT despite evidence that studies supporting associations between folate and CRT came from both American [28] and non-American populations [27, 46]. Together then, perhaps we still cannot discount the possibility of narrow and low intakes of folate contributing to the disparities between studies. Furthermore, narrow and low intakes of B vitamins and methionine could also be an explanation, in the current study, for the absence of associations between $\mathrm{B}$ vitamin and methionine intake and CRTs in persons with LS.

In our population of persons with LS, 128 persons $(27.2 \%)$ out of 470 used any folic acid- or B vitamincontaining supplement within the last month, and there would not be enough persons to conduct a meaningful analysis. However, given the potential importance of supplement use in CRT risk, we have also previously considered the relationship between supplement use and colorectal adenoma risk, but the small number of individuals using folic acid or B vitamins could only allow for an analysis investigating multivitamin use and CRA risk. We have found evidence of a slight increase in risk associated with multivitamin use, but the association was not statistically significant [64].

The absence of a clear association between dietary B vitamins and methionine and CRT risk in our study could also be in part due to the disparity in timing of the adenoma-carcinoma sequence in the general population compared to that in LS, where the progression from adenoma to carcinoma is $<4$ years [17-19] compared to roughly 10 years in the general population [65]. Following 6 years of follow-up, folic acid supplementation increased the risk of colorectal adenoma recurrence in individuals with a history of CRA [66]. Although the folic acid supplementation study was not conducted in a LS population and the exposure was folic acid rather than dietary folate intake (as in our own study), the time frame of 6 years can provide us with a general idea of how long the induction time could be. Indeed, in LS, this induction time of $<4$ years is much faster [17-19]. Even given the rapid process of initiation to malignant transformation of CRT in LS, exposure to B vitamins and methionine in this brief window could theoretically be too short to be meaningful for CRT risk.

Another explanation of our results could be that the pathways in CRT development in the general population are different from that in LS. Fearon and Vogelstein have proposed a genetic model of colorectal tumorigenesis that describes the transition from healthy colonic tissue to neoplasia through a series of steps involving the accumulation of genetic and epigenetic changes [15]. In sporadic $\mathrm{CRC}$, a mutation in the adenomatous polyposis coli (APC) gene is frequently one of the earliest events in initiating colorectal carcinogenesis [67] but is uncommon in HNPCC tumors [68]. We could infer that this and other differences in microsatellite instability and $M L H 1$ promoter hypermethylation could hypothetically alter the still-unclear fundamental mechanisms connecting folate-mediated onecarbon metabolism to CRT development.

In stratified analyses, we observed an increased risk of CRT with low vitamin B2 intake in those with the MTHFR 677TT genotype compared with MTHFR $677 \mathrm{CC}$, whereas this was not observed for high intakes in TT carriers. Our findings in this subgroup analysis were based on small numbers, so prudence should be taken when interpreting the results. The presence of the $\mathrm{T}$ allele results in a thermolabile protein and reduces MTHFR activity in vitro by approximately two-thirds in TT-homozygotes [69], and this coupled with low levels of its cofactor-riboflavin in its coenzymatic form (flavin adenine dinucleotide)—was associated with a significant increased risk of colorectal carcinogenesis in our population of MMR gene mutation carriers. Van den Donk et al. [32] have also reported inverse associations between vitamin B2 intake and risk of sporadic CRA for all MTHFR C677T genotypes but with more pronounced associations among those with the TT genotype. Low vitamin B intake was non-significantly linked to an increased risk of CRA in those with the TT genotype [32]. The significant association between low methionine intake and increased CRT risk for MTHFR 677TT individuals compared to low methionine intake in MTHFR 677CC that we observed has also been seen in a general Portuguese population [70]. Nevertheless, based on the small number of subjects in our stratified analysis, our results should be interpreted with discretion and certainly necessitate confirmation by other studies. Adequate folate status in combination with the MTHFR C677T variant is usually inversely associated with CRT risk, but low folate status in combination with the MTHFR 677TT genotype has been associated with increased risks for CRC [71-74], although this interaction has not been consistently observed $[32,75,76]$. Furthermore, potentially because of the folateantagonizing effects of alcohol, low CRC risk associated with the MTHFR 677TT genotype is negated with high alcohol intake [36, 73].

We found an interaction between dietary folate intake and alcohol intake ( $p$ interaction $=0.02$ ). Although not statistically significant, the reduction in CRT risk by high folate intake was mitigated by high alcohol intake (HR $1.23,95 \%$ CI $0.66-2.32$ for high folate/high alcohol vs. low folate/low alcohol). Alcohol is a folate antagonist, and as such interferes with folate bioavailability, transport, and metabolism [77].

The major strengths of this study are its relatively large size and prospective cohort design. Furthermore, all participants in our study were exclusively confirmed MMR 
gene mutation carriers. A high response rate of $71 \%$, which reduces the possibility of selection bias and recall, would allow our results to be generalized to other LS patients. There was also extensive information about many possible confounding factors, making possible their inclusion as covariates in our analyses.

Our study also has some limitations. As is the case with all observational studies, the potential for residual confounding, resulting from unmeasured or inadequately measured confounders, cannot be negated. Furthermore, while this study is a large prospective cohort study of MMR gene mutation carriers, it can be considered a small prospective study when compared to cohort studies in the general population, and we had limited power in our subgroup analyses. Misclassification of exposure data is possible since dietary intake was assessed using a selfadministered FFQ, and although this FFQ has been sufficiently validated $[37,38]$, it may be worthwhile for future studies to consider determining vitamin status from blood samples. Measuring vitamin status in blood also has the added advantages of accounting for uptake, distribution, and metabolism of vitamins in the body.

In conclusion, in this LS population, intake of dietary folate, other B vitamins, and methionine were unassociated with CRT development. These associations, however, may depend on MTHFR genotype. Larger studies with longer follow-up times are needed to further clarify the relationships between dietary B vitamin and methionine intake and risk of CRT in LS patients.

Acknowledgments We are grateful to all the participants of the GEOLynch cohort study. We thank Leontien Witjes (Wageningen University), Maria van Vugt (Radboud University Medical Center), Mary Velthuizen (Netherlands Foundation for the Detection for Hereditary Tumors), Alice Donselaar (Netherlands Foundation for the Detection of Hereditary Tumors), Carolien Lute (Wageningen University), and Ramazan Buyukcelik (Erasmus Medical Center) for their assistance with recruitment, data collection, DNA preparation, and genotyping. The work described in this paper was carried out with the support of the Dutch Cancer Society (KWF, Grant Number KUN2007-3842).

\section{References}

1. Bronner CE, Baker SM, Morrison PT, Warren G, Smith LG, Lescoe MK, Kane M, Earabino C, Lipford J, Lindblom A (1994) Mutation in the DNA mismatch repair gene homologue hMLH1 is associated with hereditary non-polyposis colon cancer. Nature 368(6468):258-261

2. Fishel R, Lescoe MK, Rao MR, Copeland NG, Jenkins NA, Garber J, Kane M, Kolodner R (1993) The human mutator gene homolog MSH2 and its association with hereditary nonpolyposis colon cancer. Cell 75(5):1027-1038

3. Hendriks YM, Jagmohan-Changur S, van der Klift HM, Morreau $\mathrm{H}$, van Puijenbroek M, Tops C, van Os T, Wagner A, Ausems MG, Gomez E, Breuning MH, Brocker-Vriends AH, Vasen HF,
Wijnen JT (2006) Heterozygous mutations in PMS2 cause hereditary nonpolyposis colorectal carcinoma (Lynch syndrome). Gastroenterology 130(2):312-322

4. Miyaki M, Konishi M, Tanaka K, Kikuchi-Yanoshita R, Muraoka M, Yasuno M, Igari T, Koike M, Chiba M, Mori T (1997) Germline mutation of the MSH6 as the cause of hereditary nonpolyposis colorectal cancer. Nat Genet 17(3):271-272

5. Ligtenberg MJ, Kuiper RP, Chan TL, Goossens M, Hebeda KM, Voorendt M, Lee TY, Bodmer D, Hoenselaar E, Hendriks-Cornelissen SJ, Tsui WY, Kong CK, Brunner HG, van Kessel AG, Yuen ST, van Krieken JH, Leung SY, Hoogerbrugge N (2009) Heritable somatic methylation and inactivation of MSH2 in families with Lynch syndrome due to deletion of the $3^{\prime}$ exons of TACSTD1. Nat Genet 41(1):112-117

6. Aarnio M, Mecklin JP, Aaltonen LA, Nyström-Lahti M, Järvinen HJ (1995) Life-time risk of different cancers in hereditary nonpolyposis colorectal cancer (HNPCC) syndrome. Int J Cancer 64(6):430-433

7. Aarnio M, Sankila R, Pukkala E, Salovaara R, Aaltonen LA, de la Chapelle A, Peltomaki P, Mecklin JP, Jarvinen HJ (1999) Cancer risk in mutation carriers of DNA-mismatch-repair genes. Int $\mathbf{J}$ Cancer 81(2):214-218

8. Dunlop MG, Farrington SM, Carothers AD, Wyllie AH, Sharp L, Burn J, Liu B, Kinzler KW, Vogelstein B (1997) Cancer risk associated with germline DNA mismatch repair gene mutations. Hum Mol Genet 6(1):105-110

9. Watson P, Lynch HT (2001) Cancer risk in mismatch repair gene mutation carriers. Fam Cancer 1(1):57-60

10. Vasen HF, Wijnen JT, Menko FH, Kleibeuker JH, Taal BG, Griffioen G, Nagengast FM, Meijers-Heijboer EH, Bertario L, Varesco L, Bisgaard ML, Mohr J, Fodde R, Khan PM (1996) Cancer risk in families with hereditary nonpolyposis colorectal cancer diagnosed by mutation analysis. Gastroenterology 110(4):1020-1027

11. Barrow E, Alduaij W, Robinson L, Shenton A, Clancy T, Lalloo F, Hill J, Evans DG (2008) Colorectal cancer in HNPCC: cumulative lifetime incidence, survival and tumour distribution. A report of 121 families with proven mutations. Clin Genet 74(3):233-242

12. Jenkins MA, Baglietto L, Dowty JG, Van Vliet CM, Smith L, Mead LJ, Macrae FA, St John DJ, Jass JR, Giles GG, Hopper JL, Southey MC (2006) Cancer risks for mismatch repair gene mutation carriers: a population-based early onset case-family study. Clin Gastroenterol Hepatol 4(4):489-498

13. Hampel H, Stephens JA, Pukkala E, Sankila R, Aaltonen LA, Mecklin JP, de la Chapelle A (2005) Cancer risk in hereditary nonpolyposis colorectal cancer syndrome: later age of onset. Gastroenterology 129(2):415-421

14. Watson P, Lynch HT (1994) The tumor spectrum in HNPCC. Anticancer Res 14(4B):1635-1639

15. Fearon ER, Vogelstein B (1990) A genetic model for colorectal tumorigenesis. Cell 61(5):759-767

16. Hill MJ, Morson BC, Bussey HJ (1978) Aetiology of adenomacarcinoma sequence in large bowel. Lancet 1(8058):245-247

17. Edelstein DL, Axilbund J, Baxter M, Hylind LM, Romans K, Griffin CA, Cruz-Correa M, Giardiello FM (2011) Rapid development of colorectal neoplasia in patients with Lynch syndrome. Clin Gastroenterol Hepatol 9(4):340-343

18. Rijcken FE, Hollema H, Kleibeuker JH (2002) Proximal adenomas in hereditary non-polyposis colorectal cancer are prone to rapid malignant transformation. Gut 50(3):382-386

19. Vasen HF, Nagengast FM, Khan PM (1995) Interval cancers in hereditary non-polyposis colorectal cancer (Lynch syndrome). Lancet 345(8958):1183-1184

20. Botma A, Nagengast FM, Braem MG, Hendriks JC, Kleibeuker JH, Vasen HF, Kampman E (2010) Body mass index increases 
risk of colorectal adenomas in men with Lynch syndrome: the GEOLynch cohort study. J Clin Oncol 28(28):4346-4353

21. Win AK, Dowty JG, English DR, Campbell PT, Young JP, Winship I, Macrae FA, Lipton L, Parry S, Young GP, Buchanan DD, Martinez ME, Jacobs ET, Ahnen DJ, Haile RW, Casey G, Baron JA, Lindor NM, Thibodeau SN, Newcomb PA, Potter JD, Le Marchand L, Gallinger S, Hopper JL, Jenkins MA (2011) Body mass index in early adulthood and colorectal cancer risk for carriers and non-carriers of germline mutations in DNA mismatch repair genes. Br J Cancer 105(1):162-169

22. Winkels RM, Botma A, Van Duijnhoven FJ, Nagengast FM, Kleibeuker JH, Vasen HF, Kampman E (2012) Smoking increases the risk for colorectal adenomas in patients with Lynch syndrome. Gastroenterology 142(2):241-247

23. Diergaarde B, Braam H, Vasen HF, Nagengast FM, van Muijen GN, Kok FJ, Kampman E (2007) Environmental factors and colorectal tumor risk in individuals with hereditary nonpolyposis colorectal cancer. Clin Gastroenterol Hepatol 5(6):736-742

24. Pande M, Lynch PM, Hopper JL, Jenkins MA, Gallinger S, Haile RW, LeMarchand L, Lindor NM, Campbell PT, Newcomb PA, Potter JD, Baron JA, Frazier ML, Amos CI (2010) Smoking and colorectal cancer in Lynch syndrome: results from the colon cancer family registry and the University of Texas M.D. Anderson Cancer Center. Clin Cancer Res 16(4):1331-1339

25. Botma A, Vasen HF, van Duijnhoven FJ, Kleibeuker JH, Nagengast FM, Kampman E (2013) Dietary patterns and colorectal adenomas in Lynch syndrome: the GEOLynch cohort study. Cancer 119(3):512-521

26. Burn J, Gerdes AM, Macrae F, Mecklin JP, Moeslein G, Olschwang S, Eccles D, Evans DG, Maher ER, Bertario L, Bisgaard ML, Dunlop MG, Ho JW, Hodgson SV, Lindblom A, Lubinski J, Morrison PJ, Murday V, Ramesar R, Side L, Scott RJ, Thomas HJ, Vasen HF, Barker G, Crawford G, Elliott F, Movahedi M, Pylvanainen K, Wijnen JT, Fodde R, Lynch HT, Mathers JC, Bishop DT, Ball J, Baxter L, Boussioutas A, Bradshaw N, Brewer C, Broughton M, Bulman B, Castiglione M, Clark S, Ching R, Chu C, Cina S, Cook J, Cummings C, Davies R, Debniak T, de Moncuit C, Drummond S, Ellis T, Fidalgo P, Gallinger S, Goff S, Goldberg PA, Goodman S, Harocopos C, Hutter P, Jeffers L, Jordan S, Killick P, Krauss C, Kristensen J, Langman C, Leite J, Liljegren A, Oliani C, Marks C, Membrez-Antonioli V, Miller J, Miles T, Segura PP, Pichert G, Pietersen E, Rossi G, Sala P, Sampson J, Schmocker B, Shaw J, Spigelman A, Tempesta A, Velthuizen M, Walpole I, Kerr D, Perkins S, Cuzick J, Wood LF, Steele R, Altman D, Paraskeva C, Atkin W, Hull M (2011) Longterm effect of aspirin on cancer risk in carriers of hereditary colorectal cancer: an analysis from the CAPP2 randomised controlled trial. Lancet 378(9809):2081-2087

27. Benito E, Cabeza E, Moreno V, Obrador A, Bosch FX (1993) Diet and colorectal adenomas: a case-control study in Majorca. Int J Cancer 55(2):213-219

28. Lee JE, Willett WC, Fuchs CS, Smith-Warner SA, Wu K, Ma J, Giovannucci E (2011) Folate intake and risk of colorectal cancer and adenoma: modification by time. Am J Clin Nutr 93(4):817-825

29. Sanjoaquin MA, Allen N, Couto E, Roddam AW, Key TJ (2005) Folate intake and colorectal cancer risk: a meta-analytical approach. Int J Cancer 113(5):825-828

30. Key TJ, Appleby PN, Masset G, Brunner EJ, Cade JE, Greenwood DC, Stephen AM, Kuh D, Bhaniani A, Powell N, Khaw KT (2012) Vitamins, minerals, essential fatty acids and colorectal cancer risk in the United Kingdom dietary cohort consortium. Int J Cancer 131(3):E320-E325

31. Shrubsole MJ, Yang G, Gao YT, Chow WH, Shu XO, Cai Q, Rothman N, Gao J, Wagner C, Zheng W (2009) Dietary B vitamin and methionine intakes and plasma folate are not associated with colorectal cancer risk in Chinese women. Cancer Epidemiol Biomark Prev 18(3):1003-1006

32. van den Donk M, Buijsse B, van den Berg SW, Ocke MC, Harryvan JL, Nagengast FM, Kok FJ, Kampman E (2005) Dietary intake of folate and riboflavin, MTHFR C677T genotype, and colorectal adenoma risk: a Dutch case-control study. Cancer Epidemiol Biomark Prev 14(6):1562-1566

33. de Vogel S, Dindore V, van Engeland M, Goldbohm RA, van den Brandt PA, Weijenberg MP (2008) Dietary folate, methionine, riboflavin, and vitamin B-6 and risk of sporadic colorectal cancer. J Nutr 138(12):2372-2378

34. World Cancer Research Fund/American Institute for Cancer Research (2011) Continuous update project report. Food, nutrition, physical activity, and the prevention of colorectal cancer

35. Houlston RS, Tomlinson IP (2001) Polymorphisms and colorectal tumor risk. Gastroenterology 121(2):282-301

36. Sharp L, Little J (2004) Polymorphisms in genes involved in folate metabolism and colorectal neoplasia: a HuGE review. Am J Epidemiol 159(5):423-443

37. Feunekes GI, Van Staveren WA, De Vries JH, Burema J, Hautvast JG (1993) Relative and biomarker-based validity of a food frequency questionnaire estimating intake of fats and cholesterol. Am J Clin Nutr 58(4):489-496

38. Verkleij-Hagoort AC, de Vries JH, Stegers MP, Lindemans J, Ursem NT, Steegers-Theunissen RP (2007) Validation of the assessment of folate and vitamin B12 intake in women of reproductive age: the method of triads. Eur $\mathrm{J}$ Clin Nutr 61(5):610-615

39. Netherlands Nutrition Center (2006) NEVO Nederlandse Voedingsmiddelentabel (Dutch food composition table). Netherlands Nutrition Center, The Hague

40. Baecke JA, Burema J, Frijters JE (1982) A short questionnaire for the measurement of habitual physical activity in epidemiological studies. Am J Clin Nutr 36(5):936-942

41. Pufulete M, Emery PW, Nelson M, Sanders TA (2002) Validation of a short food frequency questionnaire to assess folate intake. $\mathrm{Br}$ J Nutr 87(4):383-390

42. Drogan D, Klipstein-Grobusch K, Wans S, Luley C, Boeing H, Dierkes J (2004) Plasma folate as marker of folate status in epidemiological studies: the European investigation into cancer and nutrition (EPIC)-Potsdam study. Br J Nutr 92(3):489-496

43. Fayet F, Flood V, Petocz P, Samman S (2011) Relative and biomarker-based validity of a food frequency questionnaire that measures the intakes of vitamin $\mathrm{B}(12)$, folate, iron, and zinc in young women. Nutr Res 31(1):14-20

44. De Jong AE, Morreau H, Van Puijenbroek M, Eilers PH, Wijnen J, Nagengast FM, Griffioen G, Cats A, Menko FH, Kleibeuker JH, Vasen HF (2004) The role of mismatch repair gene defects in the development of adenomas in patients with HNPCC. Gastroenterology 126(1):42-48

45. Willett WC, Howe GR, Kushi LH (1997) Adjustment for total energy intake in epidemiologic studies. Am J Clin Nutr 65(4 Suppl.):1220S-1228S; discussion 1229S-1231S

46. Roswall N, Olsen A, Christensen J, Dragsted LO, Overvad K, Tjønneland A (2010) Micronutrient intake and risk of colon and rectal cancer in a Danish cohort. Cancer Epidemiol 34(1):40-46

47. Kabat GC, Miller AB, Jain M, Rohan TE (2008) Dietary intake of selected $\mathrm{B}$ vitamins in relation to risk of major cancers in women. Br J Cancer 99(5):816-821

48. Baron JA, Sandler RS, Haile RW, Mandel JS, Mott LA, Greenberg ER (1998) Folate intake, alcohol consumption, cigarette smoking, and risk of colorectal adenomas. J Natl Cancer Inst 90(1):57-62

49. World Cancer Research Fund/American Institute for Cancer Research (2010) Systematic literature review continuous update 
project report. The associations between food, nutrition and physical activity and the risk of colorectal cancer

50. Kim DH, Smith-Warner SA, Spiegelman D, Yaun SS, Colditz GA, Freudenheim JL, Giovannucci E, Goldbohm RA, Graham S, Harnack L, Jacobs EJ, Leitzmann M, Mannisto S, Miller AB, Potter JD, Rohan TE, Schatzkin A, Speizer FE, Stevens VL, Stolzenberg-Solomon R, Terry P, Toniolo P, Weijenberg MP, Willett WC, Wolk A, Zeleniuch-Jacquotte A, Hunter DJ (2010) Pooled analyses of 13 prospective cohort studies on folate intake and colon cancer. Cancer Causes Control 21(11):1919-1930

51. Larsson SC, Orsini N, Wolk A (2010) Vitamin B6 and risk of colorectal cancer: a meta-analysis of prospective studies. JAMA 303(11):1077-1083

52. Zhang X, Lee JE, Ma J, Je Y, Wu K, Willett WC, Fuchs CS, Giovannucci EL (2012) Prospective cohort studies of vitamin B-6 intake and colorectal cancer incidence: modification by time? Am J Clin Nutr 96(4):874-881

53. World Cancer Research Fund/American Institute for Cancer Research (2007) Food, nutrition, physical activity, and the prevention of cancer: a global perspective. AICR, Washington, DC

54. Ulrich CM (2007) Folate and cancer prevention: a closer look at a complex picture. Am J Clin Nutr 86(2):271-273

55. Kim YI (2004) Folate, colorectal carcinogenesis, and DNA methylation: lessons from animal studies. Environ Mol Mutagen 44(1):10-25

56. Song J, Sohn KJ, Medline A, Ash C, Gallinger S, Kim YI (2000) Chemopreventive effects of dietary folate on intestinal polyps in Apc+/- Msh2-/- mice. Cancer Res 60(12):3191-3199

57. Vollset SE, Clarke R, Lewington S, Ebbing M, Halsey J, Lonn E, Armitage J, Manson JE, Hankey GJ, Spence JD, Galan P, Bønaa KH, Jamison R, Gaziano JM, Guarino P, Baron JA, Logan RF, Giovannucci EL, den Heijer M, Ueland PM, Bennett D, Collins R, Peto R, Armitage J, Bowman L, Clarke R, Parish S, Peto R, Collins R, Lonn E, Yusuf S, Manson JE, Glynn R, Grodstein F, Albert CM, Cook NR, Hankey G, Eikelboom JW, Toole J, Malinow MR, Chambless LE, Spence JD, Pettigrew LC, Howard VJ, Sides EG, Wang CH, Stampfer M, Galan P, Hercberg S, Nygård $\mathrm{O}$, Ebbing $\mathrm{M}$, Nordrehaug JE, Nilsen DW, Ueland PM, Refsum H, Vollset SE, Bønaa KH, Njølstad I, Jamison R, Gaziano J, Guarino P, Baron JA, Giovannucci EA, Logan RF, denHeijer M, Blom H, Bos G, Clarke R, Halsey J, Lewington S, Bennett D, Collins R, Peto R (2013) Effects of folic acid supplementation on overall and site-specific cancer incidence during the randomised trials: meta-analyses of data on 50,000 individuals. Lancet 381(9871):1029-1036

58. Logan RF, Grainge MJ, Shepherd VC, Armitage NC, Muir KR (2008) Aspirin and folic acid for the prevention of recurrent colorectal adenomas. Gastroenterology 134(1):29-38

59. Song Y, Manson JE, Lee IM, Cook NR, Paul L, Selhub J, Giovannucci E, Zhang SM (2012) Effect of combined folic acid, vitamin $\mathrm{B}(6)$, and vitamin $\mathrm{B}(12)$ on colorectal adenoma. J Natl Cancer Inst 104(20):1562-1575

60. Wu K, Platz EA, Willett WC, Fuchs CS, Selhub J, Rosner BA, Hunter DJ, Giovannucci E (2009) A randomized trial on folic acid supplementation and risk of recurrent colorectal adenoma. Am J Clin Nutr 90(6):1623-1631

61. Qin X, Cui Y, Shen L, Sun N, Zhang Y, Li J, Xu X, Wang B, Xu X, Huo Y, Wang X (2013) Folic acid supplementation and cancer risk: a meta-analysis of randomized controlled trials. Int J Cancer 133(5):1033-1041

62. Figueiredo JC, Mott LA, Giovannucci E, Wu K, Cole B, Grainge MJ, Logan RF, Baron JA (2011) Folic acid and prevention of colorectal adenomas: a combined analysis of randomized clinical trials. Int J Cancer 129(1):192-203

63. Larsson SC, Giovannucci E, Wolk A (2005) A prospective study of dietary folate intake and risk of colorectal cancer: modification by caffeine intake and cigarette smoking. Cancer Epidemiol Biomark Prev 14(3):740-743

64. Heine-Bröring RC, Winkels RM, Botma A, van Duijnhoven FJ, Jung AY, Kleibeuker JH, Nagengast FM, Vasen HF, Kampman E (2013) Dietary supplement use and colorectal adenoma risk in individuals with Lynch syndrome: the GEOLynch Cohort Study. PLoS One 8(6):e66819

65. Winawer SJ, Fletcher RH, Miller L, Godlee F, Stolar MH, Mulrow CD, Woolf SH, Glick SN, Ganiats TG, Bond JH, Rosen L, Zapka JG, Olsen SJ, Giardiello FM, Sisk JE, Van Antwerp R, Brown-Davis C, Marciniak DA, Mayer RJ (1997) Colorectal cancer screening: clinical guidelines and rationale. Gastroenterology 112(2):594-642

66. Cole BF, Baron JA, Sandler RS, Haile RW, Ahnen DJ, Bresalier RS, McKeown-Eyssen G, Summers RW, Rothstein RI, Burke CA, Snover DC, Church TR, Allen JI, Robertson DJ, Beck GJ, Bond JH, Byers T, Mandel JS, Mott LA, Pearson LH, Barry EL, Rees JR, Marcon N, Saibil F, Ueland PM, Greenberg ER (2007) Folic acid for the prevention of colorectal adenomas: a randomized clinical trial. JAMA 297(21):2351-2359

67. Powell SM, Zilz N, Beazer-Barclay Y, Bryan TM, Hamilton SR, Thibodeau SN, Vogelstein B, Kinzler KW (1992) APC mutations occur early during colorectal tumorigenesis. Nature 359(6392):235-237

68. Konishi M, Kikuchi-Yanoshita R, Tanaka K, Muraoka M, Onda A, Okumura Y, Kishi N, Iwama T, Mori T, Koike M, Ushio K, Chiba M, Nomizu S, Konishi F, Utsunomiya J, Miyaki M (1996) Molecular nature of colon tumors in hereditary nonpolyposis colon cancer, familial polyposis, and sporadic colon cancer. Gastroenterology 111(2):307-317

69. Frosst P, Blom HJ, Milos R, Goyette P, Sheppard CA, Matthews RG, Boers GJ, den Heijer M, Kluijtmans LA, van den Heuvel LP (1995) A candidate genetic risk factor for vascular disease: a common mutation in methylenetetrahydrofolate reductase. Nat Genet 10(1):111-113

70. Guerreiro CS, Carmona B, Goncalves S, Carolino E, Fidalgo P, Brito M, Leitao CN, Cravo M (2008) Risk of colorectal cancer associated with the C677T polymorphism in 5,10-methylenetetrahydrofolate reductase in Portuguese patients depends on the intake of methyl-donor nutrients. Am J Clin Nutr 88(5):1413-1418

71. Martinez ME, Thompson P, Jacobs ET, Giovannucci E, Jiang R, Klimecki W, Alberts DS (2006) Dietary factors and biomarkers involved in the methylenetetrahydrofolate reductase genotypecolorectal adenoma pathway. Gastroenterology 131(6):1706-1716

72. Slattery ML, Potter JD, Samowitz W, Schaffer D, Leppert M (1999) Methylenetetrahydrofolate reductase, diet, and risk of colon cancer. Cancer Epidemiol Biomark Prev 8(6):513-518

73. Ma J, Stampfer MJ, Giovannucci E, Artigas C, Hunter DJ, Fuchs C, Willett WC, Selhub J, Hennekens CH, Rozen R (1997) Methylenetetrahydrofolate reductase polymorphism, dietary interactions, and risk of colorectal cancer. Cancer Res 57(6):1098-1102

74. Le Marchand L, Donlon T, Hankin JH, Kolonel LN, Wilkens LR, Seifried A (2002) B-vitamin intake, metabolic genes, and colorectal cancer risk (United States). Cancer Causes Control 13(3):239-248

75. Kim J, Cho YA, Kim DH, Lee BH, Hwang DY, Jeong J, Lee HJ, Matsuo K, Tajima K, Ahn YO (2012) Dietary intake of folate and alcohol, MTHFR C677T polymorphism, and colorectal cancer risk in Korea. Am J Clin Nutr 95(2):405-412

76. Lee JE, Wei EK, Fuchs CS, Hunter DJ, Lee IM, Selhub J, Stampfer MJ, Willett WC, Ma J, Giovannucci E (2012) Plasma folate, methylenetetrahydrofolate reductase (MTHFR), and colorectal cancer risk in three large nested case-control studies. Cancer Causes Control 23(4):537-545

77. Mason JB, Choi SW (2005) Effects of alcohol on folate metabolism: implications for carcinogenesis. Alcohol 35(3):235-241 